\title{
Effect of Soil Flexibility on Analysis and Design of Building
}

\author{
Gagan Malviya *, Vivek Garg ** \\ *(M.Tech. Scholar, Structural Engineering, MANIT, Bhopal \\ **(Assistant professor, Department of Civil Engineering, MANIT, Bhopal
}

\begin{abstract}
Generally in the analysis and design of multi-story building frame it is assumed that the base is fixed but in actual the structure is ultimately supported on soil which is flexible in nature. This flexibility of soil may vary due to load-settlement characteristics of soil, variation in soil strata below the foundation level, seasonal variation of soil property etc. The flexible nature of soil causes differential settlement between foundations on application of loads which in turn redistribute the structural forces as well as design. The present paper attempts to acknowledge the effect of soil flexibility in analysis and design of structure. A G+7 4-bay by 4-bay RCC residential building frame supported on sandy soil and situated in seismic zone V as per IS: 1893(part 1)-2002 is analysed usingStaad pro software. Initially the building frame is modelled and analysed assuming fixed base and support reactions are determined for different load cases. The foundation sizes for different supports are calculated by using Staad foundation software. The fixed support is replaced by a spring of equivalent foundation stiffness to perform flexible base analysis. In flexible support analysis the maximum total settlement and differential settlement between footings is found to be $44.19 \mathrm{~mm}$ and $8.14 \mathrm{~mm}$ respectively which is neglected in conventional analysis. The variation in values of settlement is more critical in case of seismic loading. Soil flexibility causes significant variation in values of support moment compared to vertical support reaction. The flexibility of soil also affects the forces in beams and columns. The requirement of steel reinforcement is reduced by nearly $7 \%$ in flexible support system compared to fixed base. The study shows that the soil flexibility redistributed the structural forces and affects the analysis and design of structure. In present study analysis and design of structure assuming flexible base is found to be more accurate and economical.
\end{abstract}

Keywords: Total settlement, differential settlement, beam and column forces, Staad pro, Staad foundation.

\section{INTRODUCTION}

In past several investigators studied the response of the multi-storey frame subjected to differential settlement. The conventional analysis of structure is carried out assuming foundation resting on unyielding supports. However, the behaviour of structure is greatly influenced by the flexible nature of soil beneath the foundation. This flexibility of soil varies with different type of soil, modulus of subgrade reaction, bearing capacity and load settlement characteristics of soil etc. The flexibility causes total and differential settlement and redistribution of forces and moments in structures. Unlike total settlement the consequences of differential settlement are much detrimental to serviceability of structure such as cracks, tilting, deflection etc. Hence to determine the effect of soil flexibility on structure the flexible base analysis should be performed. The flexible base analysis is more realistic and safe compared to conventional analysis. According to IS 1904-1986 the permissible value of differential settlement for multi-storey frame is $0.002 \mathrm{~L}$ (Where $\mathrm{L}$ is span length).

\section{LITERATURE REVIEW}

Several investigators studied the influence of soil flexibilityon buildings. They performed the studies by changing various parameters of soil and structure and found that due to soil flexibility the structural forces are altered. Some of noteworthy configuration of researchers in this field arediscussed below.

Weigel et al.(1989)developed a Pascal program to evaluate the settlement of a isolated footing supported on over consolidated and normally consolidated clay and sand layers including the effect of the structural rigidity of a frame. The settlement calculated using one dimensional consolidation theory for clay and Schmertmann's theory for sands considering three frame with varying moment of inertia they concluded that due to the differential settlement change in forces of the super structure is significant when move from flexible to rigid frame.

Dutta et al. (1999)studied differential settlement of building frames with isolated footings. The change in column bending moments and axial force due to flexural stiffness of structural member considering different parameter was analysed. It was observed that the column moment 
in settlement condition was significantly higher as compared to no settlement condition.

Roy and Dutta(2001)investigated the change in structural behaviour of a building frame with the differential settlements of footing. It was investigated that the differential settlements among various footings result in a redistribution of the column forces, beam forces the amount of which depends on the rigidity of the structure and characteristics of the soil beneath the footings.

Fenton and Griffiths (2002)evaluated settlement below a foundation by using the finite element method. By generating and analysing multiple realizations, the statistics and density functions of total and differential settlements are estimated. They prepared the two models with single spread footing for total settlement and a pair of spread footing for the differential settlement and they concluded that the differential settlement causes more complicate variation as compare to total settlement.

Lee and Salgado (2002)evaluatedthe loadsettlement response of vertically loaded footings placed in sands using both the finite element method with a nonlinear stress-strain model and the conventional elastic approach. Calculations are made for both normally consolidated and heavily over consolidated sands with various relative densities. The value of cone penetration resistance was obtained by conpoint. The settlements are computed using CPT value.

Sneha et al. (2009)estimated the vertical and lateral displacement assuming the footing as a spring rested on variety of soils with different sub grade modulus reaction Ks. The building is analysed for different wind and seismic zones. The vertical settlement and lateral displacement are estimated for different storey buildings in which the columns are having different heights. Also calculated the behaviour of building frame supported different footing size and soil.

Jayalekshmi et al. (2009)analysed Seismic response of $\mathrm{RC}$ space frame building with isolated footing resting on differentstiffness layered soil. Stiffness of layered soil from very soft to stiff range is considered. The analysis of structure is performed in ANSYSsoftware. Structure is presented the effect of layer soil on natural period and base shear and concluded that the effect of soil structure interaction increases the seismic base shear.

Agrawal and Hora (2010)evaluated the effect of differential settlements on the forces in the frame members, bending moments in the foundation beam and the contact pressure distribution below the foundation beam is investigated. The nonlinear interaction analysis of a two-bay two-storey plane building frame-soil system has been carried out. The computer programme developed in FORTRAN-90 for nonlinear interaction analysis of frame foundation beam soil system. They founded that the shear forces and bending moments in superstructure (different at different floor level) get significantly altered due to differential settlements of soil mass.

Smit (2010)performed an experiment which is designed according to British Standards and Euro code of 3D, 5-bay by 5-bay, 6 storey flat slabs RC frame with pad foundations on clay. The behaviour of the designed structure undergoing differential settlement was then analysed by means of finite element analyses. His result shows 3D deformation of the structure due to settlement and importance of soil structure stiffness ratio. He concluded that the structure forces changes due to differential settlement.

Jenifer et al. (2012)studied the effect of Soil-structure interaction on multi storeyed buildings with various foundation systems. Multi storeyed buildings with rigid and flexible foundation support subjected to seismic forces were analysed under different soil conditions like hard, medium and soft. The buildings were analysed by Response spectrum method using software STAAD Pro.As a result of this they concluded that as the base changes from rigid to flexible the changes in the forces (moments, story drift, and base shear) are more. Hence suitable foundation system considering the effect of Soil stiffness has to be adopted while designing building frames for seismic forces.

Lahri and Garg (2015) analysed various plane frames (different story and number of bay) in the Staad pro software applying a displacement load on the support and evaluated the effect of this applied load on different member of portal frame by changing various parameters such stiffness of structure, length of beam, length of column, number of bays, number of storey etc. on this basis concluded that on increasing the beam length, column height the axial force, shear force, moments are reduced whereas on increasing inertia of beam and column and number of bay the axial force, shear force and moments are increased.

\section{PROPOSED WORK}

In the present study aRCC space frame is designed considering the effect of soil flexibility. The structure has been modelledand analysed in Staad pro and Staad foundation software. The work procedure adopted for analysis and design are as follows.

A $\mathrm{G}+74$ bay by 4 bay $\mathrm{RCC}$ residential building frame supported on sandy soil and situated in seismic zone-V (as per IS: 1893-2002) as shown in fig. 1 has been modelled in Staad pro software. 
The geometric properties of structure are shown in table 1 . Initially the structure is assumed to be fixed at base.The structure is loaded with imposed load of $3.5 \mathrm{kN} / \mathrm{m}^{2}$ and the seismic loads are as per IS: 1893-2002. The support reactions obtained from the fixed base analysis is used to calculate the foundation size in Staad foundation software. The bearing capacity of medium sandy soil is assumed to be $200 \mathrm{kN} / \mathrm{m}^{2}$. The modulus of subgrade reaction (K) is assumed to be $12000 \mathrm{kN} / \mathrm{m}^{3}$ for standard size plate (i.e. $0.3 \mathrm{~m} \times 0.3 \mathrm{~m}$ ). The values of modulus of subgrade reaction for the different size of foundation are calculated.The fixed support is then replaced by a spring of equivalent foundation stiffness to perform flexible base analysis. The total Settlement, differential settlement and support reactions of foundation column and beam forces of structure and material requirement are compared between fixed base and flexible base system.

Table 1 Geometric properties of structure

\begin{tabular}{|c|c|}
\hline Description & Values \\
\hline Material & Concrete $(\mathrm{M} \mathrm{25})$ \\
\hline Modulus of Elasticity & $2.17 \times 10^{7} \mathrm{kN} / \mathrm{m}^{2}$ \\
\hline Density of Concrete & $23.56 \mathrm{kN} / \mathrm{m}^{3}$ \\
\hline No. of Story & 8 \\
\hline No. of Bays (Both direction) & $5 \mathrm{~m}$ \\
\hline Bay width (Both direction) & $3.5 \mathrm{~m}$ \\
\hline Floor to Floor Height & $1.5 \mathrm{~m}$ \\
\hline Foundation Below Plinth level & $600 \mathrm{~mm} \times 600 \mathrm{~mm}$ \\
\hline $\begin{array}{c}\text { Size of Column } \\
\text { (Ground level to G+3) } \\
\text { (G+4 to G+7) }\end{array}$ & $450 \mathrm{~mm} \times 450 \mathrm{~mm}$ \\
\hline Size of Beams & $300 \mathrm{~mm} \times 500 \mathrm{~mm}$ \\
\hline Type of Support & Flexible support \\
\hline Thickness of Outer wall & $230 \mathrm{~mm}$ \\
\hline Thickness of Inner wall & $130 \mathrm{~mm}$ \\
\hline
\end{tabular}

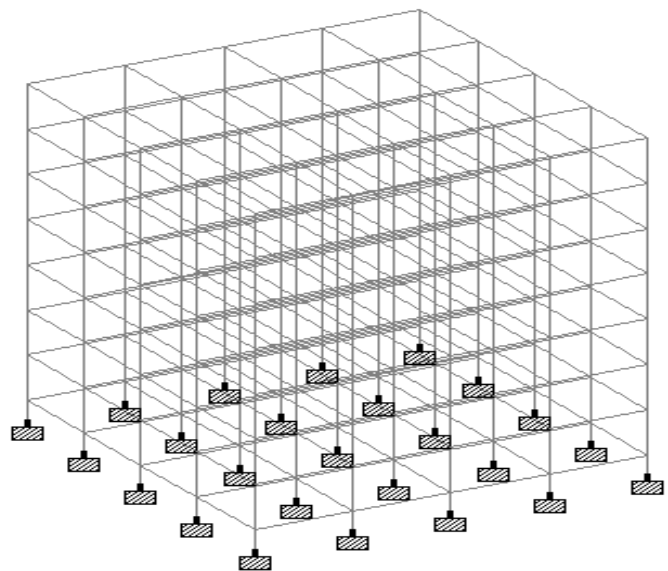

Isometric view

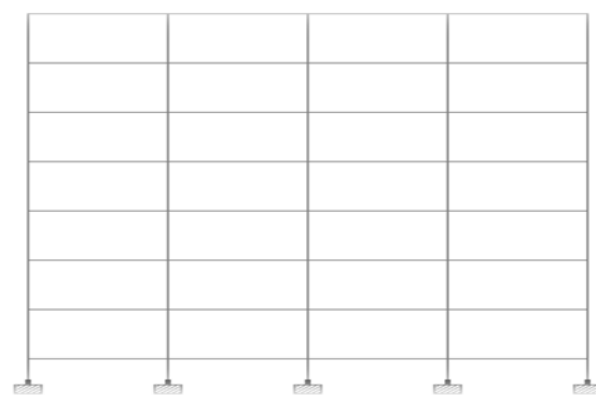

Elevation 


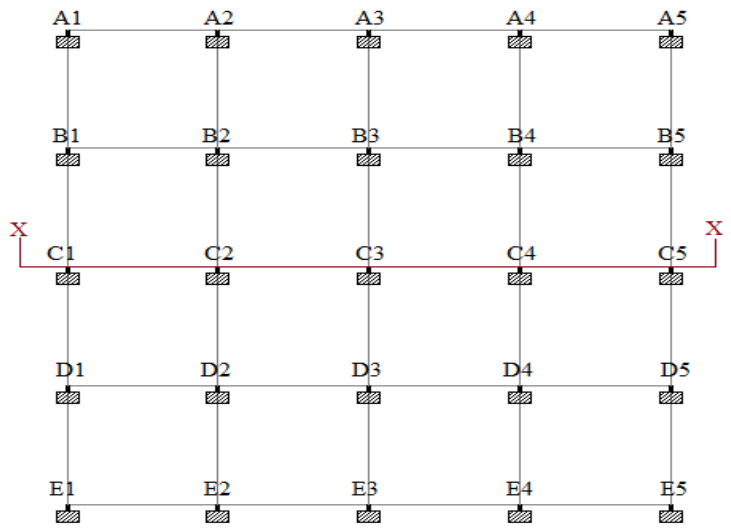

Foundation plan

Fig.1 Proposed model

\section{RESULTS AND DISCUSSION}

In thisstudy total and differential settlements in flexible support system are calculated. The variation of support reaction, column and beam forces and the requirement of material are also discussed forcorresponding load cases. Since the model is symmetrical about X-axis and Z-axis. The load combinations considered for analysis and design are gravity load and seismic load in positive $\mathrm{X}$ direction. The results obtained are as follows.

\subsection{Total Settlement of Foundation}

Table 3 shows the results of total settlement obtained in gravity as well as seismic loading.Maximum and minimum values of settlements are observed as $44.19 \mathrm{~mm}$ and 28.05 $\mathrm{mm}$ which is neglectedin conventional case. The variation in values of total settlement is more in case of seismic loading.

\subsection{Differential Settlement of Foundation}

The magnitudes of differential settlements between the footings are calculated in both the direction (along $\mathrm{x}$-direction and $\mathrm{z}$-direction) in flexible support system as shown in table 4 . Maximum differential settlement is observed between $\mathrm{C} 1$ and $\mathrm{C} 2$ footings (i.e. $8.14 \mathrm{~mm}$ ) at section X-X (shown in fig. 1 foundation plan) in seismic loading case.

\subsection{Effect of soil flexibility on Support reaction}

The comparison of support reaction between fixed and flexible support system for various load cases are shown in table 5 . The soil flexibility changes critical value of vertical support reaction and support moments. The critical values of vertical support reaction are reduced whereas the critical values of torsional moment and bending moments are increased in flexible base system compared to fixed base system. The variation in support moment is much higher than variation in vertical support reaction which signifies that the support moments are more influenced by soil flexibility.

\subsection{Effect of Soil Flexibility on Column Forces}

The comparison of column forces between fixed and flexible support system at section $\mathrm{X}-\mathrm{X}$ are shown in table 6 . The effect of soil flexibility causes variation in axial force, shear force and bending moment in columns. The critical values of shear force and bending moments are found more in flexible support system compared to fixed support system. Fig. 2 shows that the flexible base analysis gives significant values of bending moment for interior columns which are negligible in fixed base analysis under gravity loading.

\subsection{Effect of Soil Flexibility on Beam Forces}

Table 7 shows the comparison of beam force between fixed and flexible support system at section X-X. The soil flexibility causes significant variation in shear force and bending moments. The critical values of shear force and bending moments are found to be higher in flexible base system compared to fixed based system. The variations of bending moments in beams at section $\mathrm{X}-\mathrm{X}$ are shown in fig. 2. This shows that the variation in bending moments is more at lower storey of structure compared to upper storey in gravity as well as seismic loading.

\subsection{Effect of Soil Flexibility on Material Requirement}

Material required for fixed base and flexible base structure is shown in table 8 . The table depicts that quantity of steel is approximately $7 \%$ less for flexible base system compared to fixed base system. 
Table 3 Vertical settlement Uy (mm) of footings resting on flexible base for different load cases

\begin{tabular}{|c|c|c|c|c|c|}
\hline \multirow{2}{*}{ Footing type } & \multicolumn{3}{|c|}{ Coordinate } & $\begin{array}{c}\text { Gravity loading } \\
\text { (DL+LL) }\end{array}$ & $\begin{array}{c}\text { Seismic loading } \\
\text { (DL+LL+EQ+X) }\end{array}$ \\
\cline { 2 - 4 } & $\mathrm{X}$ & $\mathrm{Y}$ & $\mathrm{Z}$ & -34.93 & -28.05 \\
\hline A1 & 0 & -1.5 & 0 & -37.04 & -35.08 \\
\hline A2 & 5 & -1.5 & 0 & -37.69 & -37.69 \\
\hline A3 & 10 & -1.5 & 0 & -37.04 & -38.99 \\
\hline A4 & 15 & -1.5 & 0 & -34.93 & -41.80 \\
\hline A5 & 20 & -1.5 & 0 & -37.04 & -30.50 \\
\hline B1 & 0 & -1.5 & 5 & -40.29 & -38.45 \\
\hline B2 & 5 & -1.5 & 5 & -41.14 & -41.14 \\
\hline B3 & 10 & -1.5 & 5 & -40.29 & -42.13 \\
\hline B4 & 15 & -1.5 & 5 & -37.04 & -43.57 \\
\hline B5 & 20 & -1.5 & 5 & -37.69 & -31.19 \\
\hline C1 & 0 & -1.5 & 10 & -41.14 & -39.33 \\
\hline C2 & 5 & -1.5 & 10 & -42.05 & -42.05 \\
\hline C3 & 10 & -1.5 & 10 & -41.14 & -42.95 \\
\hline C4 & 15 & -1.5 & 10 & -37.69 & \\
\hline C5 & 20 & -1.5 & 10 & & \\
\hline
\end{tabular}

Table 4 Differential settlement (mm) offootings resting on flexible support for different load cases

\begin{tabular}{|c|c|c|c|}
\hline \multicolumn{2}{|c|}{ Footing type } & \multirow{2}{*}{$\begin{array}{c}\text { Gravity loading } \\
\text { (DL+LL) }\end{array}$} & \multirow{2}{*}{$\begin{array}{c}\text { Seismic loading } \\
(\mathrm{DL}+\mathrm{LL}+\mathrm{EQ}+\mathrm{X})\end{array}$} \\
\hline Left & Right & & \\
\hline \multicolumn{4}{|c|}{ Along $\mathrm{X}$ direction } \\
\hline A1 & A2 & 2.11 & 7.03 \\
\hline $\mathrm{A} 2$ & A3 & 0.66 & 2.62 \\
\hline A3 & A4 & -0.66 & 1.30 \\
\hline A4 & A5 & -2.11 & 2.81 \\
\hline B1 & B2 & 3.26 & 7.96 \\
\hline B2 & B3 & 0.85 & 2.69 \\
\hline B3 & B4 & -0.85 & 0.99 \\
\hline B4 & B5 & -3.26 & 1.44 \\
\hline $\mathrm{C} 1$ & $\mathrm{C} 2$ & 3.45 & 8.14 \\
\hline $\mathrm{C} 2$ & $\mathrm{C} 3$ & 0.91 & 2.72 \\
\hline $\mathrm{C} 3$ & $\mathrm{C} 4$ & -0.91 & 0.90 \\
\hline $\mathrm{C} 4$ & $\mathrm{C} 5$ & -3.45 & 1.24 \\
\hline \multicolumn{4}{|c|}{ Along $\mathrm{Z}$ direction } \\
\hline A1 & B1 & 2.11 & 2.45 \\
\hline $\mathrm{A} 2$ & B2 & 3.26 & 3.37 \\
\hline $\mathrm{A} 3$ & B3 & 3.45 & 3.45 \\
\hline A4 & B4 & 3.26 & 3.14 \\
\hline A5 & B5 & 2.11 & 1.77 \\
\hline B1 & $\mathrm{C} 1$ & 0.66 & 0.70 \\
\hline B2 & $\mathrm{C} 2$ & 0.85 & 0.88 \\
\hline B3 & $\mathrm{C} 3$ & 0.91 & 0.91 \\
\hline B4 & $\mathrm{C} 4$ & 0.85 & 0.82 \\
\hline B5 & C5 & 0.66 & 0.62 \\
\hline
\end{tabular}

Note: -ve sign indicate that left footing settlement is more than that of right footing 
Table 5 Comparisonof support reaction between flexible and fixed base system

\begin{tabular}{|c|c|c|c|c|c|c|c|c|c|c|}
\hline \multirow{2}{*}{ Load case } & \multirow{2}{*}{ Limits } & \multicolumn{3}{|c|}{ Fixed base } & \multicolumn{3}{|c|}{ Flexible base } & \multicolumn{3}{|c|}{ Ratio (Flexible base / Fixed base) } \\
\hline & & Fy1 & Mx1 & Mz1 & Fy2 & $\mathrm{Mx} 2$ & Mz2 & Fy $2 /$ Fy 1 & $\mathrm{Mx} 2 / \mathrm{Mx} 1$ & $\mathrm{Mz} 2 / \mathrm{Mz} 1$ \\
\hline $1.5 \mathrm{DL}+1.5 \mathrm{LL}$ & $\begin{array}{l}\text { Min to } \\
\operatorname{Max}\end{array}$ & $\begin{array}{c}1896.71 \text { to } \\
3616.00\end{array}$ & $\begin{array}{l}-9.62 \text { to } \\
9.62\end{array}$ & -9.62 to 9.62 & $\begin{array}{c}2151.67 \text { to } \\
3498.88\end{array}$ & $\begin{array}{l}-12.95 \\
\text { to } 12.95\end{array}$ & $\begin{array}{c}-12.07 \text { to } \\
12.07\end{array}$ & $\begin{array}{c}0.94 \text { to } \\
1.13\end{array}$ & $* *$ & $* *$ \\
\hline $\begin{array}{c}1.2 \mathrm{DL}+1.2 \mathrm{LL}+1.2 \\
\mathrm{EQ}+\mathrm{X}\end{array}$ & $\begin{array}{l}\text { Min to } \\
\operatorname{Max}\end{array}$ & $\begin{array}{c}1077.19 \text { to } \\
2892.80\end{array}$ & $\begin{array}{l}-7.70 \\
\text { to } 7.70\end{array}$ & $\begin{array}{c}249.32 \text { to } \\
287.36\end{array}$ & $\begin{array}{c}1382.42 \text { to } \\
2859.21\end{array}$ & $\begin{array}{l}-10.36 \\
\text { to } 10.36\end{array}$ & $\begin{array}{c}296.86 \text { to } \\
352.47\end{array}$ & $\begin{array}{l}0.89 \text { to } \\
1.28\end{array}$ & $\begin{array}{c}-53.17 \text { to } \\
63.16\end{array}$ & $\begin{array}{l}1.18 \text { to } \\
1.25\end{array}$ \\
\hline $1.5 \mathrm{DL}+1.5 \mathrm{EQ}+\mathrm{X}$ & $\begin{array}{l}\text { Min to } \\
\operatorname{Max}\end{array}$ & $\begin{array}{c}1136.87 \text { to } \\
2875.29\end{array}$ & $\begin{array}{c}-7.51 \text { to } \\
7.51\end{array}$ & $\begin{array}{c}313.04 \text { to } \\
357.36\end{array}$ & $\begin{array}{l}1390.59 \text { to } \\
2856.26\end{array}$ & $\begin{array}{l}-8.40 \\
\text { to } 8.40\end{array}$ & $\begin{array}{c}373.26 \text { to } \\
438.72\end{array}$ & $\begin{array}{l}0.89 \\
\text { to } 1.2\end{array}$ & $\begin{array}{c}-2.58 \text { to } \\
8.69\end{array}$ & $\begin{array}{l}1.18 \text { to } \\
1.25\end{array}$ \\
\hline $0.9 \mathrm{DL}+1.5 \mathrm{EQ}+\mathrm{X}$ & $\begin{array}{l}\text { Min to } \\
\operatorname{Max}\end{array}$ & $\begin{array}{l}462.04 \text { to } \\
1959.72\end{array}$ & $\begin{array}{c}-4.56 \\
\text { to } 4.56\end{array}$ & $\begin{array}{l}316.00 \text { to } \\
357.15\end{array}$ & $\begin{array}{l}664.89 \text { to } \\
1895.69\end{array}$ & $\begin{array}{l}-5.15 \\
\text { to } 5.15\end{array}$ & $\begin{array}{c}376.15 \text { to } \\
438.72\end{array}$ & $\begin{array}{c}0.85 \text { to } \\
1.44\end{array}$ & $\begin{array}{l}-2.79 \\
\text { to } 8.85\end{array}$ & $\begin{array}{l}1.18 \text { to } \\
1.25\end{array}$ \\
\hline
\end{tabular}

Fy- Vertical Support Reaction $(\mathrm{kN})$

$\mathrm{Mx}$ - Torsional Moment $(\mathrm{kN}-\mathrm{m})$

Mz- Bending Moment (kN-m)

Table 6 Comparison of column forces between flexible and fixed base system at section X-X

\begin{tabular}{|c|c|c|c|c|c|c|c|c|c|c|}
\hline \multirow{2}{*}{ Load case } & \multirow{2}{*}{ Limits } & \multicolumn{3}{|c|}{ Fixed base } & \multicolumn{3}{|c|}{ Flexible base } & \multicolumn{3}{|c|}{ Ratio (Flexible base / Fixed base) } \\
\hline & & FX1 & FY1 & Mz1 & FX2 & FY2 & $\mathrm{Mz} 2$ & $\mathrm{FX} 2 / \mathrm{FX} 1$ & FY2/FY1 & $\mathrm{Mz} 2 / \mathrm{Mz} 1$ \\
\hline $1.5 \mathrm{DL}+1.5 \mathrm{LL}$ & $\begin{array}{l}\text { Min to } \\
\operatorname{Max}\end{array}$ & $\begin{array}{c}-3587.38 \text { to } \\
3616.00\end{array}$ & $\begin{array}{c}-38.85 \text { to } \\
38.85\end{array}$ & $\begin{array}{c}-74.84 \text { to } \\
74.84\end{array}$ & $\begin{array}{c}-3470.25 \text { to } \\
3498.88\end{array}$ & $\begin{array}{l}-60.62 \text { to } \\
60.62\end{array}$ & $\begin{array}{c}-116.39 \text { to } \\
116.39\end{array}$ & $\begin{array}{c}0.95 \text { to } \\
1.31\end{array}$ & $\begin{array}{l}1.44 \text { to } \\
29.42\end{array}$ & $\begin{array}{l}1.25 \text { to } \\
40.51\end{array}$ \\
\hline $\begin{array}{c}1.2 \mathrm{DL}+1.2 \mathrm{LL}+1.2 \\
\mathrm{EQ}+\mathrm{X}\end{array}$ & $\begin{array}{l}\text { Min to } \\
\text { Max }\end{array}$ & $\begin{array}{c}-2869.90 \text { to } \\
2892.80\end{array}$ & $\begin{array}{c}-132.45 \text { to } \\
132.45\end{array}$ & $\begin{array}{c}-152.36 \text { to } \\
297.75\end{array}$ & $\begin{array}{c}-2836.30 \text { to } \\
2859.21\end{array}$ & $\begin{array}{c}-154.84 \text { to } \\
154.84\end{array}$ & $\begin{array}{c}-242.31 \text { to } \\
352.47\end{array}$ & $\begin{array}{c}0.91 \text { to } \\
1.41\end{array}$ & $\begin{array}{l}-0.57 \text { to } \\
2.55\end{array}$ & ** \\
\hline $1.5 \mathrm{DL}+1.5 \mathrm{EQ}+\mathrm{X}$ & $\begin{array}{l}\text { Min to } \\
\text { Max }\end{array}$ & $\begin{array}{c}-2846.66 \text { to } \\
2875.29\end{array}$ & $\begin{array}{c}-164.10 \text { to } \\
164.10\end{array}$ & $\begin{array}{c}-192.55 \text { to } \\
371.79\end{array}$ & $\begin{array}{c}-2827.63 \text { to } \\
2856.26\end{array}$ & $\begin{array}{c}-181.27 \text { to } \\
181.27\end{array}$ & $\begin{array}{c}-286.13 \text { to } \\
438.72\end{array}$ & $\begin{array}{c}0.89 \text { to } \\
1.10\end{array}$ & $\begin{array}{c}0.48 \text { to } \\
2.27\end{array}$ & $\begin{array}{c}-0.34 \text { to } \\
5.31\end{array}$ \\
\hline $0.9 \mathrm{DL}+1.5 \mathrm{EQ}+\mathrm{X}$ & $\begin{array}{l}\text { Min to } \\
\text { Max }\end{array}$ & $\begin{array}{c}-1942.54 \text { to } \\
1959.72\end{array}$ & $\begin{array}{c}-163.49 \text { to } \\
163.49\end{array}$ & $\begin{array}{c}-185.77 \text { to } \\
371.50\end{array}$ & $\begin{array}{c}-1878.51 \text { to } \\
1895.69\end{array}$ & $\begin{array}{c}-181.27 \text { to } \\
181.27\end{array}$ & $\begin{array}{c}-272.99 \text { to } \\
438.72\end{array}$ & $\begin{array}{c}0.85 \text { to } \\
1.16\end{array}$ & $\begin{array}{l}0.70 \text { to } \\
5.32\end{array}$ & $\begin{array}{c}-1.35 \text { to } \\
1.90\end{array}$ \\
\hline
\end{tabular}

Fx- Axial Force $(\mathrm{kN})$

Fy- Shear Force $(\mathrm{kN})$

Mz- Bending Moment (kN-m)

Table 7 Comparison of beam forces between flexible and fixed base system at section X-X

\begin{tabular}{|c|c|c|c|c|c|c|c|}
\hline \multirow{2}{*}{ Load case } & \multirow{2}{*}{ Limits } & \multicolumn{2}{|c|}{ Fixed base } & \multicolumn{2}{c|}{ Flexible base } & \multicolumn{2}{c|}{ Ratio (Flexible base/ Fixed base) } \\
\cline { 3 - 8 } & & FY1 & MZ1 & FY2 & MZ2 & FY2/FY1 & MZ2/MZ1 \\
\hline $1.5 \mathrm{DL}+1.5 \mathrm{LL}$ & Min to Max & 48.27 to 121.08 & -117.88 to 117.88 & 19.25 to148.07 & -187.79 to 187.79 & 0.40 to 1.58 & -0.88 to 2.70 \\
\hline $\begin{array}{c}1.2 \mathrm{DL}+1.2 \mathrm{LL}+ \\
1.2 \mathrm{EQ}+\mathrm{X}\end{array}$ & Min to Max & -1.20 to 183.08 & -315.04 to 13.65 & -8.35 to 195.70 & -347.18 to 70.18 & $*$ & -3.67 to 24.51 \\
\hline $1.5 \mathrm{DL}+1.5 \mathrm{EQ}+\mathrm{X}$ & Min to Max & -25.97 to 194.54 & -356.35 to 14.30 & -37.40 to 205.97 & -382.03 to 41.75 & -78.45 to 14.13 & -1.33 to 5.17 \\
\hline $0.9 \mathrm{DL}+1.5 \mathrm{EQ}+\mathrm{X}$ & Min to Max & -59.04 to 160.18 & -324.18 to -4.58 & -69.82 to 170.97 & -348.08 to 15.53 & -0.66 to 2.35 & -1.40 to 3.35 \\
\hline
\end{tabular}

Fy- Shear Force $(\mathrm{kN})$

Mz- Bending Moment (kN-m)

Note:- $* *$ shows insignificant values,+ve moment value indicates hogging moment, -ve moment value indicates sagging moment

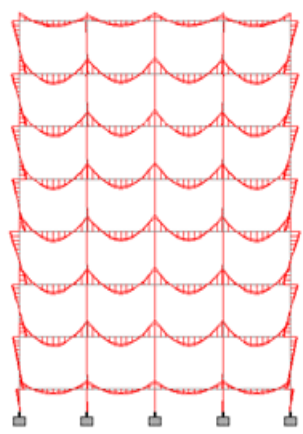

Fixed support

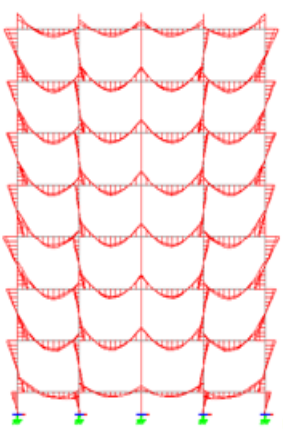

Flexible support

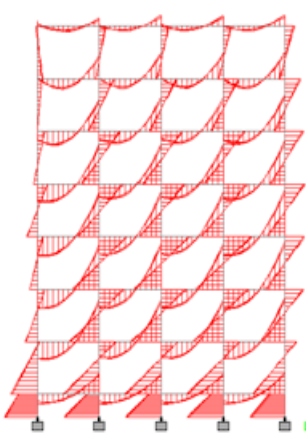

Fixed support

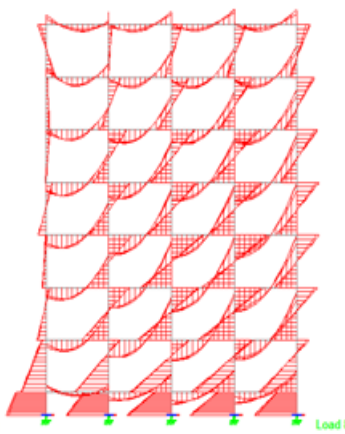

Flexible support

Gravity Loading

Seismic Loading (1.2DL+1.2LL+1.2EQ+X)

Fig. 3 Bending moment diagram at section $\mathrm{X}-\mathrm{X}$ 
Table 8 Comparison of material quantities between flexible and fixed base system

\begin{tabular}{|c|c|c|c|}
\hline Material & $\begin{array}{c}\text { Fixed base } \\
\text { system }\end{array}$ & $\begin{array}{c}\text { Flexible base } \\
\text { system }\end{array}$ & Remarks \\
\hline Concrete & $419 \mathrm{~m}^{3}$ & $419 \mathrm{~m}^{3}$ & $\begin{array}{c}\text { Quantity of steel is approximately 7\% less for } \\
\text { flexible base system compared to fixed base system }\end{array}$ \\
\hline Steel & 451 quintal & 420 quintal &
\end{tabular}

\section{CONCLUSION}

A G+7 RCC space frame is analysed in Staad pro software considering the effect of soil flexibility. The soil flexibility causes settlementsof foundations, change in support reactions, redistribution of forces in beam and column and also affects the requirement of reinforcement for design. The following points have been concluded as a result of present work:

a) The maximum values of total settlement and differential settlement are obtained $44.19 \mathrm{~mm}$ and $8.14 \mathrm{~mm}$ respectively in flexible support case which is neglected in the conventional analysis. The values of total and differential settlements arefound more criticalin seismic loading compared to gravity loading.

b) Significant variation in support reaction is observed due to the flexibility of soil. The flexibility of soil affects the critical value of support moment and vertical support reaction. The variation insupport moments are found more compared to variation invertical support reaction.

c) The soil flexibility causes redistribution of axial force, shear force and bending moment in columns. The variation in critical values of shear force and bending moment is found more compared to axial force. Flexible base analysis gives significant values of bending moment for interior columns which are negligible in fixed base analysis under gravity loading.

d) The soil flexibility causes redistribution of shear force and bending moment in beams. The critical values of shear force and bending moment in flexible base system is found more compared to fixed base system. The variations in bending moment is found more in lower storey compared to upper storey of structure.

e) Approximately 7\% lesser steel is required for flexible support system compared to fixed support system due to the redistribution of forces. In present case analysis and design of structure assuming flexible base is found to be more accurate and economical also.

\section{REFERENCES}

[1] T. A. Weigel, K. J. Ott and D. J. Hagerty, Load Redistribution in Frame with Settling Footings, Journal of Computing in Civil Engineering, Vol. 3, No.1,1989, 75-92.
[2] S. C. Dutta, A. Maiti and D. Moitra, Effect of Soil-structure Interactions on Column Moment of Building Frames, Journal of the Institution of Engineers, Vol. 80,2001, 1-7.

[3] R. Roy and S. C. Dutta, Differential Settlement among Isolated Footings of Building Frames: The Problem, Its Estimation and Possible Measures, International Journal of Applied Mechanics and Engineering, Vol. 6, No. 1,2001, 165186.

[4] J. Lee and R. Salgado Estimation of Footing Settlement in Sand, The International Journal of Geomechanics Vol. 2, No.1, 2002, $1-28$.

[5] I. L. Sneha, K. V. G. D. Balajiand, P. C. Kumar, Study on Vertical Settlement and Lateral Displacement in Different Types of Soils,International Journal of Engineering and Technical Research, Vol. 2, No. 9,2009, 107-111.

[6] B.R. Jayalekshmi, Katta. Venkataramana and R. Shivashankar, Seismic, Response of Space Frames with Isolated Footing on Layered Soil,International Journal of Earth .$R$ Sciences and Engineering Vol. 2, No. 1,2009, 68-72.

[7] R. Agrawal and M. S. Hora, Effect of Differential Settlements on Nonlinear Interaction Behaviour of Plane FrameSoil,ARPN Journal of Engineering and Applied Science, Vol. 5, No. 7, 2010, 75-87.

[8] R. M. J. Priyanka, N. Anand and S. Justin, Studies on Soil Structure Interaction of Multi Storeyed Buildings with Rigid And Flexible Foundation, International Journal of Emerging Technology and Advanced Engineering, Vol. 2, No. 12,2012, 111-118.

[9] A. Lahri and V. Garg, Effect of Differential Settlement on Frame Forces - A Parametric Study, International Journal of Research in Engineering and Technology Vol. 4, No. 9,2015, 454-464.

[10] Smit G. The behaviour of Modern Flexible Framed Structures undergoing Differential Settlement, (Ph.D. thesis) University of Southampton, England,2010

[11] IS 8009 (Part-1): 1976. Indian Standard Code for Practice for Calculation of Settlement of Foundation, Bureau of Indian Standard, New Delhi. 
[12] IS 1904:1986, Indian Standard Code of Practice for Design and Construction of Foundations in Soils: General Requirements (third revision), Bureau of Indian Standard, New Delhi.

[13] IS 456: 2000. Indian Standard Plain and Reinforce concrete code of practice (fourth revision), Bureau of Indian Standard, New Delhi.

[14] IS 1893 (Part-1):2002. Criteria for Earthquake Resistant Design of Structures, Bureau of Indian Standard, New Delhi.

[15] K. R. Arora, Soil Mechanics and Foundation Engineering(Standard Publishers, New Delhi, 1997)

[16] P. C. Varghese, Foundation Engineering (Prentice Hall of India Private Limited, New Delhi, 2007)

[17] B. C. Punamia, Soil Mechanics and Foundations (Laxmi publication pvt. Ltd. New Delhi, 2012) 